Received: 2016.01.23

Accepted: 2016.02 .29

Published: 2016.10 .07
Authors' Contribution:

Study Design A

Data Collection B

Statistical Analysis C

Data Interpretation D

Manuscript Preparation E

Literature Search F

Funds Collection $G$
Corresponding Author:

Source of support:

\title{
Association of STin2 Variable Number of Tandem Repeat (VNTR) Polymorphism of Serotonin Transporter Gene with Lifelong Premature Ejaculation: A Case-Control Study in Han Chinese Subjects
}

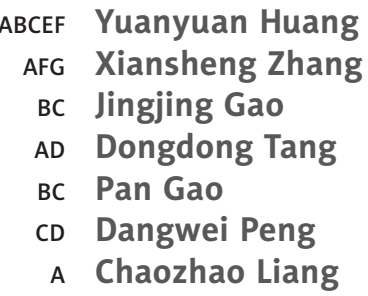

Department of Urology, The First Affiliated Hospital of Anhui Medical University, Hefei, Anhui, P.R. China

Background: The STin2 VNTR polymorphism has a variable number of tandem repeats in intron 2 of the serotonin transporter gene. We aimed to explore the relationship between STin2 VNTR polymorphism and lifelong premature ejaculation (LPE).

Material/Methods:

Xiansheng Zhang, e-mail: xiansheng-zhang@163.com

This study was funded by the National Natural Science Foundation of China (No. 81571429)

We recruited a total of 115 outpatients who complained of ejaculating prematurely and who were diagnosed as LPE, and 101 controls without PE complaint. Allelic variations of STin2 VNTR were genotyped using PCR-based technology. We evaluated the associations between STin2 VNTR allelic and genotypic frequencies and LPE, as well as the intravaginal ejaculation latency time (IELT) of different STin2 VNTR genotypes among LPE patients.

Results: The patients and controls did not differ significantly in terms of any characteristic except age. A significantly higher frequency of STin2.12/12 genotype was found among LPE patients versus controls $(P=0.026)$. Frequency of patients carrying at least 1 copy of the 10-repeat allele was significantly lower compared to the control group ( $28.3 \%$ vs. $41.8 \%, \mathrm{OR}=0.55 ; 95 \% \mathrm{Cl}=0.31-0.97, P=0.040)$. In the LPE group, the mean IELT showed significant difference in STin2.12/12 genotype when compared to those with STin2.12/10 and STin2.10/10 genotypes. The mean IELT in 10-repeat allele carriers was 50\% longer compared to homozygous carriers of the STin2.12 allele. Conclusions: Our results indicate the presence of STin2.10 allele is a protective factor for LPE. Men carrying the higher expression genotype STin2. 12/12 have shorter IELT than 10-repeat allele carriers.

MeSH Keywords: $\quad$ Polymorphism, Genetic • Premature Ejaculation • Serotonin Plasma Membrane Transport Proteins

Full-text PDF: $\quad$ http://www.medscimonit.com/abstract/index/idArt/897720

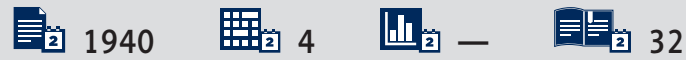




\section{Background}

Premature ejaculation $(\mathrm{PE})$ is one of the most common male sexual dysfunctions, with prevalence ranging from $3 \%$ to $30 \%$ according to different definitions [1,2]. In general, PE is divided into lifelong PE (LPE) and acquired PE (APE) [3]. The latest definition of LPE includes 3 points: (i) IELT<1 minute; (ii) the inability to delay ejaculation; and (iii) negative personal consequences [4].

Previous studies of twins and familial studies had proved the genetic predisposition in LPE [5-7]. A twins study in Finnish men indicated that 0.30 of the etiology was a result of hereditary effect [7]. However, twins and familial studies did not clarify which genetic variant might explain the genetic effects in LPE. To explore this problem, genetic association studies may be a possible approach. The susceptibility to LPE was considered to be a polygenic pattern, such as those genes linked to the metabolism of serotonin (5-HT) and those related to the expression of serotonin transporter (5-HTT). The focus of genetic research on 5-HT has had a very strict theoretical basis. Firstly, various selective serotonin reuptake inhibitors (SSRIs) were successfully used in the treatment of PE, and dapoxetine became the first approved drug for PE treatment [8,9]. Secondly, animal experiments also demonstrated the role of $5-\mathrm{HT}$ in ejaculation [10,11]. Decreased duration of intravaginal ejaculation latency time (IELT) was associated with decreased 5-HT or the dysfunction of different $5-\mathrm{HT}$ receptors [12]. Furthermore, SNPs located in genes encoding 5-HT receptors were also reported to play a role in IELT of patients with PE [13-16].

SLC6A4, which encodes 5-HTT, locates on chromosome 17q11.1-17q12 of the human genome [17]. Three common polymorphisms were described: an ins/del in the promoter, called 5-HTTLPR; a variable number of tandem repeat (VNTR) in intron 2, called STin2; and a SNP polymorphism in the noncoding 3'-UTR. In fact, 5-HTTLPR has been studied thoroughly, but the effect and function of STin2 VNTR is not yet clear. It has been proved to include 10-repeat and 12-repeat alleles of a 16/17 bp element in all ethnicities, and the rare 9-repeat allele appears only in people of European or African descent $[18,19]$. STin2 VNTR works as a transcriptional regulator, and the transcriptional activity is determined by the number of repeats, with the STin2.12 having the highest expression $[20,21]$. Therefore, STin2 VNTR could affect the amount of 5-HTT. Many studies had linked VNTR with disorders such as depression, bipolar depression, and a predisposition to obsessive compulsive disorder [18,22,23].

Although many studies have explored SLC6A4 and LPE [24-28], only 1 of them studied STin2 VNTR [27], and there have been no such studies in Chinese populations. Considering the important role of the serotonergic system in ejaculatory function, we aimed to determine whether STin2 VNTR is related to LPE in China.

\section{Material and Methods}

\section{Subjects and assessments}

The current study was carried out between October 2012 and October 2015. Each participant was informed of the purpose of the study and signed the informed consent. The initial evaluation of each subject completed a detailed face-to-face interview by an andrologist, including a questionnaire and physical examination. LPE in our study was defined according to the definition of ISSM [4]. Finally, 115 patients with LPE were recruited by referral from the Andrology Outpatient Clinic. At the same time, 101 controls without PE complaint were enrolled from the medical examination center.

Subjects had to meet the following inclusion criteria: (I) heterosexual male patient aged 20-60 years; (II) Han descent and speaking Chinese; (III) in a regular sexual relationship with 1 female partner for $\geq 6$ months. None of the subjects had mental or other major medical diseases. None of the participants had received antidepressants or phosphodiesterase type $5 \mathrm{in}$ hibitors before enrolling in the trial. Patients with a urinary infection or disorders of the nervous system were also excluded from the study. We obtained $2 \mathrm{ml}$ of EDTA-anticoagulated peripheral blood samples from every participant. The study was approved by the Ethics Committee of the First Affiliated Hospital of Anhui Medical University (No.20150047).

\section{Genotyping}

Genomic DNA was extracted from peripheral blood using the Puregene DNA extraction kit (Qiagen, Hilden, Germany) following the manufacturer's protocol. Allelic-specific PCR was used to determine STin2 VNTR polymorphism. We designed a pair of primers using the Primer3 Software Online Program. Oligonucleotide primers were as follows: forward 5'-TGGCGAGATTTGACTTTTCTACC-3' and reverse 5'-CTGAGCTTCATCAAGGGGAAC-3' were used to amplify the STin2 VNTR region. A 20- $\mu$ l mixture was ready for PCR amplification, including HotStarTaq buffer, $3.0 \mathrm{mM} \mathrm{Mg}{ }^{2+}$, $0.3 \mathrm{mM}$ dNTP, $0.1 \mu \mathrm{M}$ of primers, $1 \mathrm{U}$ HotStarTaq polymerase (Qiagen, Inc.), and $1 \mu \mathrm{l}$ template DNA. PCR conditions were as follows: $15 \mathrm{~min}$ of initial denaturation at $95^{\circ} \mathrm{C} ; 11$ cycles of $94^{\circ} \mathrm{C}$ for $20 \mathrm{~s}$ and $62-0.5^{\circ} \mathrm{C}$ per cycle for $40 \mathrm{~s}$ and $68^{\circ} \mathrm{C}$ for $2 \mathrm{~min}$; followed by 24 cycles of $20 \mathrm{~s}$ of denaturation at $94^{\circ} \mathrm{C}, 56^{\circ} \mathrm{C}$ for $40 \mathrm{~s}$ and $2 \mathrm{~min}$ of extension at $68^{\circ} \mathrm{C}$, and a final extension of $60 \mathrm{~min}$ at $60^{\circ} \mathrm{C}$. After digestion, the products were analyzed on a 3730 DNA analyzer (ABI, California). Two technicians called genotypes independently by visual observation of peak sizes using GeneMapper 4.0. 
Table 1. Comparision of the demographic characteristics in PE and control group.

\begin{tabular}{|c|c|c|c|c|}
\hline \multirow{2}{*}{ Characteristics } & \multirow{2}{*}{$\begin{array}{c}\text { PE group } \\
N=114(\%)\end{array}$} & \multirow{2}{*}{$\begin{array}{c}\text { Control group } \\
N=101 \text { (\%) }\end{array}$} & \multirow{2}{*}{$t / \chi^{2}$} & \multirow{2}{*}{$P$ value* } \\
\hline & & & & \\
\hline Age, years & $35.3 \pm 7.8$ & $31.7 \pm 8.1$ & 16.135 & $<0.001^{\star * *}$ \\
\hline $\mathrm{BMI}, \mathrm{kg} / \mathrm{m}^{2}$ & $22.1 \pm 2.1$ & $21.6 \pm 1.9$ & 1.576 & 0.116 \\
\hline Duration of relation, years & $10.7 \pm 5.1$ & $9.4 \pm 5.3$ & 1.832 & 0.068 \\
\hline Smoking & $76 \quad(66.7)$ & $78 \quad(77.2)$ & 2.939 & 0.860 \\
\hline Drinking & $62 \quad(54.4)$ & $52 \quad(51.5)$ & 0.181 & 0.671 \\
\hline Marital status (merried) & $99 \quad(86.8)$ & $92 \quad(91.1)$ & 0.974 & 0.324 \\
\hline Educational level & & & 7.718 & 0.052 \\
\hline Primary school & $9 \quad(7.9)$ & $11 \quad(10.9)$ & & \\
\hline Middle school & $25 \quad(21.9)$ & $20 \quad(19.8)$ & & \\
\hline High school & $19 \quad(16.7)$ & $31 \quad(30.7)$ & & \\
\hline University & $61 \quad(53.5)$ & $39 \quad(38.6)$ & & \\
\hline Occupational status & & & - & $0.064^{\star \star}$ \\
\hline Workers & $22(19.3)$ & $27 \quad(26.7)$ & & \\
\hline Drivers & $10 \quad(8.8)$ & $5 \quad(5.0)$ & & \\
\hline Farmers & $6 \quad(5.3)$ & $(1.0)$ & & \\
\hline Officials & $17 \quad(14.9)$ & $27 \quad(26.7)$ & & \\
\hline Businessmen & $15 \quad(13.2)$ & $11 \quad(10.9)$ & & \\
\hline Other occupations & $44 \quad(38.6)$ & $30 \quad(29.7)$ & & \\
\hline Monthly income (RMB) & & & 4.132 & 0.127 \\
\hline$<1,000$ & $5 \quad(4.4)$ & $12 \quad(11.9)$ & & \\
\hline $1,000-3,000$ & $49 \quad(43.0)$ & $40 \quad(39.6)$ & & \\
\hline$>3,000$ & $60 \quad(52.6)$ & $49 \quad(48.5)$ & & \\
\hline
\end{tabular}

Data were expressed as mean \pm standard deviation (SD) or count (percentage), as appropriate. BMI - body mass index; RMB - Renminbi; PE - premature ejaculation. * Difference between two subgroups was assessed by two-tailed $t$-test or Chi-square test, as appropriate. ${ }^{* *}$ Except results of Fisher exact test. ${ }^{* * *}$ Significant difference compared with control.

\section{Statistical analyses}

The participants were classified according to alleles and genotypes. For the quantitative data, results are expressed as mean \pm standard deviation (SD) and a 2-tailed $t$-test was used. Chisquare and Fisher exact tests were used to compare the genotype proportions. After the normality and homoscedasticity test, analyses of variance (ANOVA) using IELT as a variate were performed to test differences between different genotypes. All statistical evaluations were performed with SPSS 17.0 (SPSS Inc., Chicago, United States) for Windows. $P<0.05$ was considered statistically significant.

\section{Results}

\section{Demographic characteristics}

Among 216 subjects who met the inclusion criteria, only 1 patient was excluded from the present study because of sample coagulation. Finally, there were 114 patients and 101 controls completing the study. Demographic characteristics are summarized in Table 1. The patients and controls showed no significant difference in terms of any characteristic except age (35.3 \pm 7.8 vs. $31.7 \pm 8.1, P<0.001)$. However, because LPE is assumed be lifelong, the difference did not affect the comparability of the 2 groups.

\section{STin2 VNTR allelic and genotypic frequencies distribution}

STin2 VNTR allelic frequencies are shown in Table 2. In our study, the most common allele was STin2.12 (patients: $82.5 \%$, 
Table 2. Results of STin2 VNTR polymorphism in patients and control group.

\begin{tabular}{|c|c|c|c|c|c|}
\hline & \multicolumn{2}{|c|}{ PE group } & \multicolumn{2}{|c|}{ Control group } & \multirow[b]{2}{*}{$P$ value* } \\
\hline & $\begin{array}{c}\text { Count } \\
(N=114)\end{array}$ & $\begin{array}{c}\text { Frequency } \\
\text { (\%) }\end{array}$ & $\begin{array}{c}\text { Count } \\
(\mathrm{N}=101)\end{array}$ & $\begin{array}{c}\text { Frequency } \\
\text { (\%) }\end{array}$ & \\
\hline STin2 allele & & & & & 0.182 \\
\hline STin2.12 & 188 & 82.5 & 152 & 75.2 & 0.067 \\
\hline STin2.10 & 38 & 16.7 & 47 & 23.3 & 0.086 \\
\hline STin 2.9 & 2 & 0.9 & 3 & 1.5 & $0.669^{* *}$ \\
\hline STin2 genotype & & & & & $0.108^{* \star *}$ \\
\hline STin2.12/12 & 81 & 71.1 & 57 & 56.4 & $0.026^{\#}$ \\
\hline STin2.12/10 & 26 & 22.8 & 35 & 34.7 & 0.054 \\
\hline STin $2.10 / 10$ & 6 & 5.3 & 6 & 5.9 & 0.892 \\
\hline STin2.9/12 & 0 & 0 & 3 & 3.0 & - \\
\hline STin2.9/9 & 1 & 0.9 & 0 & 0 & - \\
\hline
\end{tabular}

Data were expressed as count and frequency. ${ }^{*}$ Difference between two subgroups was assessed by Chi-square test. ${ }^{* *}$ Except results of Fisher exact test. ${ }^{* * *}$ STin2.9/12 and STin2.9/9 genotypes were excluded from analyses. \# Significant difference compared with control.

Table 3. Results of dominant models of the polymorphisms of the STin2 VNTR genotype.

\begin{tabular}{|c|c|c|c|c|c|c|c|}
\hline Dominant models & STin2 genotype & \multicolumn{2}{|c|}{$\begin{array}{l}\text { LPE group } \\
\text { count (\%) }\end{array}$} & \multicolumn{2}{|c|}{$\begin{array}{l}\text { Control group } \\
\text { count (\%) }\end{array}$} & OR $(95 \% \mathrm{Cl})$ & P value* \\
\hline \multirow{2}{*}{ STin2.12 dominant } & $12 / 12+12 / 10$ & 107 & $(94.7)$ & 92 & (93.9) & 1.00 & 0.799 \\
\hline & $10 / 10$ & 6 & (5.3) & 6 & (6.1) & $0.86(0.27-2.76)$ & \\
\hline \multirow{2}{*}{ STin2.10 dominant } & $12 / 12$ & 81 & (71.7) & 57 & $(58.2)$ & 1.00 & $0.040^{\star *}$ \\
\hline & $12 / 10+10 / 10$ & 32 & $(28.3)$ & 41 & $(41.8)$ & $0.55(0.31-0.97)$ & \\
\hline \multirow{3}{*}{ Codominant } & $12 / 12$ & 81 & (71.7) & 57 & $(58.2)$ & 1.00 & 0.108 \\
\hline & $12 / 10$ & 26 & $(23.0)$ & 35 & $(35.7)$ & $0.52(0.28-0.96)$ & \\
\hline & $10 / 10$ & 6 & (5.3) & 6 & (6.1) & $0.70(0.22-2.29)$ & \\
\hline
\end{tabular}

Data were expressed as count (percentage). ${ }^{*}$ Difference between two subgroups was assessed by logistic regression analysis.

** Statistical significant after logistic regression analyses. OR - odds ratio; $\mathrm{Cl}$ - confidence interval.

controls: $75.2 \%)$, and no significant difference was found between the 2 groups $(P=0.182)$. The STin2.9/12 and STin2.9/9 genotypes were infrequent, so they were excluded from further analyses. The distribution of genotypes of patients and controls followed HWE. The results showed a significantly higher frequency of STin2.12/12 genotype in LPE patients than in controls $(P=0.026)$. Interestingly, the less common STin2.9 allele was present in our study, which was found in people of European or African descent in previous studies.

\section{Correlation between STin2 VNTR dominant models and the risk of PE}

Table 3 shows results of analyses under the 3 models: (I) dominant STin2. 12 model (STin2.12/12+STin2.12/10 vs. STin2.10/10), (II) dominant STin2.10 model (STin2.10/10+STin2.12/10 vs. STin2.12/12), and (III) codominant model (STin2.12/12 vs. STin2.12/10 vs. STin2.10/10). To investigate the association between the 3 models and the risk of PE, binary logistic regression models were fitted. In the codominant model, we found a significantly lower frequency of STin2.12/10 in the LPE patients ( $23.0 \%$ vs. $35.7 \%, \mathrm{OR}=0.52,95 \% \mathrm{Cl}=0.28-0.96)$, although the 
Table 4. Comparision of intravaginal ejaculation latency time (IELT) of STin2 genotype in LPE group.

\begin{tabular}{|c|c|c|c|c|c|}
\hline & Count & $\begin{array}{l}\text { Median } \\
\text { IELT (second) }\end{array}$ & $\begin{array}{l}\text { Geometric mean } \\
\text { IELT (second) }\end{array}$ & $\begin{array}{c}\text { Mean } \\
\text { IELT (second) }\end{array}$ & $95 \% \mathrm{Cl}$ of mean \\
\hline \multicolumn{6}{|l|}{ Genotype } \\
\hline STin2.12/12 & 81 & 22.00 & 19.36 & $22.68 \pm 11.41^{\star \star, \#}$ & $20.16-25.20$ \\
\hline STin2.12/10 & 26 & 34.50 & 32.10 & $33.62 \pm 9.13^{\# \#}$ & $29.93-37.31$ \\
\hline STin2.10/10 & 6 & 31.5 & 32.26 & $33.17 \pm 9.26^{\# \#}$ & $23.45-42.89$ \\
\hline \multicolumn{6}{|l|}{ STin2.10 dominant } \\
\hline STin2.12/12 & 81 & 22.00 & 19.36 & $22.68 \pm 11.41$ & $20.16-25.20$ \\
\hline STin2.12/10+10/10 & 32 & 33.00 & 32.13 & $33.53 \pm 9.01^{\# \#}$ & $30.28-36.78$ \\
\hline Sum & 113 & 25.00 & 22.34 & $25.75 \pm 11.82$ & $23.55-27.95$ \\
\hline
\end{tabular}

*** Difference between Mean IELT of subgroups was assessed by one-way ANOVA analysis. ** Significant difference compared with STin2.12/10. \# Significant difference compared with STin2.10/10. \#\# Significant difference compared with STin2.12/12.

IELT - intravaginal ejaculation latency time; $\mathrm{Cl}$ - confidence interval.

difference was not statistically significant $(P=0.108)$. A statistically significant association of the dominant STin2.10 model of STin2 was observed. In this model, the combined frequency of STin 2.10 carriers was significantly lower in patients with LPE when compared with controls ( $28.3 \%$ vs. $41.8 \%$, OR $=0.55$, $95 \% \mathrm{Cl}=0.31-0.97, P=0.040)$.

\section{Comparison of IELT of different STin2 VNTR genotypes in the LPE group}

The IELT distribution is shown in Table 4. The mean IELTs were $22.68 \pm 11.41 \mathrm{~s}, 33.62 \pm 9.13 \mathrm{~s}$, and $33.17 \pm 9.26 \mathrm{~s}$ for STin2.12/12, STin2.12/10, and STin2.10/10, respectively. After the normality and homoscedasticity test, ANOVA of IELT was performed. The results showed significant difference in patients with STin2.12/12 when compared to STin2.12/10 and STin2.10/10 genotypes (STin2.12/12 vs. STin2.12/10; $P=0.001 ; \operatorname{STin} 2.12 / 12$ vs. STin2.10/10; $P=0.024)$. According to the STin2.10 dominant model, the IELT results of STin2.12/12 also showed a significant difference compared to STin2.12/10+ STin2.10/10 genotypes $(P=0.001)$. The fold-increase of the mean IELT in the STin2.12/10 and STin2.10/10 genotypes compared to STin2.12/12 genotype was 1.48 . These data indicate that STin 2.10 carriers on average had nearly a $50 \%$ longer intravaginal ejaculation time compared to STin2.12 homozygous in this study.

\section{Discussion}

Recently, polymorphisms in SLC6A4 have been increasingly associated with LPE, especially 5-HTTLPR polymorphism. But the other polymorphism in SLC6A4, STin2 VNTR, has received less attention.
Our study evaluated 114 patients and 101 controls for the relationship between STin2 VNTR and LPE. The allelic frequency of the STin2.12 was 0.825 in patients and 0.752 in controls, which showed no significant difference $(P=0.067)$. There was a significant difference in STin2.12/12 genotype, which was more common in the LPE group $(P=0.026)$. However, our results contradicted a previous study by Zuccarello et al. [27], which showed no difference between these 2 groups in genotypic and allelic frequency. More studies and meta-analyses of STin2 VNTR polymorphisms in this field are needed.

We also found a significant association between LPE and STin2.10 in the dominant model. Our data demonstrate that STin2.12/10 and STin2.10/10 genotypes, which carry the lower transcriptional activity STin 2.10 allele, were protective genotypes when compared with the STin2.12/12 genotype. One explanation may be that the STin2.10 allele is dominant to the STin2.12 allele.

A third major finding was that IELT in the patients group was associated with STin2 VNTR. STin2.10 allele carriers had a longer IELT than those with STin2.12/12 genotypes. This result is consistent with psychopharmacological results from studies on 5-HT neurotransmission. Animal studies have shown that decreased 5-HT level can accelerate the process of ejaculation [10]. Evidence shows that the STin2.12 allele has higher transcriptional activity than the STin2.10 allele [29]. Therefore, the men carrying the higher expressing allele homozygote STin2.12/12 could have more functioning $5-\mathrm{HTT}$, thus leading to lower $5-\mathrm{HT}$ availability [18]. Our results add to this knowledge.

The effect of STin2 VNTR on ejaculatory function may be quite complicated. On the one hand, gene frequencies of STin2 VNTR vary significantly among different races and ethnicities, and is 
more common in Japanese (0.997) than in African Americans (0.713) and white Americans (0.523) [30]. Our sample size of participants, as well as the relative homogeneity of demographic and clinical characteristics, make our study distinct. On the other hand, the function of Stin2 VNTR is still not clear. It may have a synergistic effect together with other polymorphisms on ejaculation, such as 5-HTTLPR [31]. Further research on genegene interaction effects in LPE are needed.

Regarding treatment of SSRIs in LPE, only 1 study found that therapeutic effects were related to both STin2 VNTR and 5- HTTLPR polymorphisms [32]. The findings indicated STin2.12/12 genotype responded better to sertraline $(P=0.001)$. We will plan to replicate the present study in this interesting field in the future.

\section{Conclusions}

To the best of our knowledge, this is the first study to focus on the STin2 VNTR polymorphism in Chinese patients with

\section{References:}

1. Goldstein I: Premature to early ejaculation: a sampling of manuscripts regarding the most common male sexual dysfunction published in the IJIR: The Journal of Sexual Medicine. Int J Impot Res, 2003; 15(5): 307-8

2. Montorsi F: Prevalence of premature ejaculation: A global and regional perspective. J Sex Med, 2005; 2: 96-102

3. Godpodinoff ML: Premature ejaculation: clinical subgroups and etiology. Sex Marital Ther, 1989; 15(2): 130-34

4. MCMahon CG, Althof SE, Waldinger MD et al: An evidence-based definition of lifelong premature ejaculation: report of the International Society for Sexual Medicine (ISSM) ad hoc committee for the definition of premature ejaculation. J Sex Med, 2008; 5(7): 1590-606

5. Jern $P$, Santtila $P$, Witting $K$ et al: Premature and delayed ejaculation: genetic and environmental effects in a population-based sample of Finnish twins. J Sex Med, 2007; 4(6): 1739-49

6. Waldinger $M$, Rietschel $M$, Nothen $M$ et al: Familial occurrence of primary premature ejaculation. Psychiatr Genet, 1998; 8: 37-40

7. Jern $P$, Santtila $P$, Johansson A et al: Evidence for a genetic etiology to ejaculatory dysfunction. Int J Impot Res, 2009; 21(1): 62-67

8. Waldinger MD, Hengeveld MW, Zwinderman AH et al: Effect of SSRI antidepressants on ejaculation: A double-blind, randomized, placebo-controlled study with fluoxetine, fluvoxamine, paroxetine, and sertraline. J Clin Psychopharmacol, 1998; 18(4): 274-81

9. Hatzimouratidis K, Amar E, Eardley I et al: Guidelines on male sexual dysfunction: erectile dysfunction and premature ejaculation. Eur Urol, 2010; 57(5): 804-14

10. Hull EM, Dominguez JM: Sexual behavior in male rodents. Horm Behav, 2007; 52(1): 45-55

11. Ahlenius S, Larsson K: Evidence for an involvement of 5-HT1B receptors in the inhibition of male rat ejaculatory behavior produced by 5-HTP. Psychopharmacology, 1998; 137: 374-82

12. Waldinger $M$, Berendsen $H$, Blok $B$ et al: Premature ejaculation and serotonergic antidepressantsinduced delayed ejaculation: The involvement of the serotonergic system. Behav Brain Res, 1998; 92: 111-18

13. Jern $P$, Westberg $L$, Johansson $A$ et al: $A$ study of possible associations between single nucleotide polymorphisms in the serotonin receptor $1 \mathrm{~A}, 1 \mathrm{~B}$, and $2 \mathrm{C}$ genes and self-reported ejaculation latency time. J Sex Med, 2012; 9(3): 866-72

14. Luo S, Lu Y, Wang F et al: Association between polymorphisms in the serotonin $2 \mathrm{C}$ receptor gene and premature ejaculation in Han Chinese subjects. Urol Int, 2010; 85(2): 204-8
LPE. Our present results indicate that STin2 VNTR polymorphism is related to LPE. In summary, men with at least 1 copy of STin2.10 allele were at lower risk of PE than men with other variant at this locus. The current study shows that the STin2 VNTR polymorphism is associated with IELTs of LPE. Patients with STin2.12/12 genotypes had significantly shorter IELT than men with other genotypes.

\section{Competing interests}

There are no conflicts of interests to disclose.

\section{Acknowledgements}

We thank all patients and controls who provided the plasma and information necessary for this study. We also thank Shanghai Genesky Bio-Tech Co, Ltd. (www.geneskybiotech.com) for help with the genotype testing.

15. Janssen PK, Schaik R, Olivier B et al: The $5-\mathrm{HT} 2 \mathrm{C}$ receptor gene Cys $23 \mathrm{Se}$ polymorphism influences the intravaginal ejaculation latency time in Dutch Caucasian men with lifelong premature ejaculation. Asian J Androl, 2014; 16(4): 607-10

16. Janssen PK, van Schaik R, Zwinderman AH et al: The 5-HT1A receptor $C(1019)$ $G$ polymorphism influences the intravaginal ejaculation latency time in Dutch Caucasian men with lifelong premature ejaculation. Pharmacol Biochem Behav, 2014; 121: 184-88

17. Lesch K, Balling U, Gross J et al: Organization of the human serotonin trans porter gene. J Neural Transm Gen Sect, 1994; 95: 157-62

18. Sarosi A, Gonda X, Balogh G et al: Association of the STin2 polymorphism of the serotonin transporter gene with a neurocognitive endophenotype in major depressive disorder. Prog Neuropsychopharmacol Biol Psychiatry, 2008; 32(7): 1667-72

19. Ali FR, Vasiliou SA, Haddley K et al: Combinatorial interaction between two human serotonin transporter gene variable number tandem repeats and their regulation by CTCF. J Neurochem, 2010; 112(1): 296-306

20. Fiskerstrand CE, Lovejoy EA, Quinn JP: An intronic polymorphic domain often associated with susceptibility to affective disorders has allele dependent differential enhancer activity in embryonic stem cells. FEBS Lett, 1999; 458(2): 171-74

21. MacKenzie A, Quinn J: A serotonin transporter gene intron 2 polymorphic region, correlated with affective disorders, has allele-dependent differential enhancer-like properties in the mouse embryo. Proc Natl Acad Sci USA, 1999; 96(26): 15251-55

22. Kunugi $H$, Hattori $M$, Kato $T$ et al: Serotonin transporter gene polymorphisms: Ethnic difference and possible association with bipolar affective disorder. Mol Psychiatry, 1997; 2(6): 457-62

23. Baca-Garcia E, Vaquero-Lorenzo C, Diaz-Hernandez $M$ et al: Association between obsessive-compulsive disorder and a variable number of tandem repeats polymorphism in intron 2 of the serotonin transporter gene. Prog Neuropsychopharmacol Biol Psychiatry, 2007; 31(2): 416-20

24. Janssen PK, Bakker SC, Rethelyi J et al: Serotonin transporter promoter region (5-HTTLPR) polymorphism is associated with the intravaginal ejaculation latency time in Dutch men with lifelong premature ejaculation. J Sex Med, 2009; 6(1): 276-84

25. Ozbek E, Tasci Al, Tugcu V et al: Possible association of the 5-HTTLPR serotonin transporter promoter gene polymorphism with premature ejaculation in a Turkish population. Asian J Androl, 2009; 11(3): 351-55 
26. Safarinejad MR: Polymorphisms of the serotonin transporter gene and their relation to premature ejaculation in individuals from Iran. J Urol, 2009, 181(6): 2656-61

27. Zuccarello $D$, Ghezzi $M$, Pengo $M$ et al: No difference in 5 -HTTLPR and Stin2 polymorphisms frequency between premature ejaculation patients and controls. J Sex Med, 2012; 9(6): 1659-68

28. Jern $P$, Eriksson $E$, Westberg $L$ : $A$ reassessment of the possible effects of the serotonin transporter gene linked polymorphism 5-HTTLPR on premature ejaculation. Arch Sex Behav, 2013; 42(1): 45-49

29. Bah J, Lindstrom $M$, Westberg $L$ et al: Serotonin transporter gene polymorphisms: Effect on serotonin transporter availability in the brain of suicide attempters. Psychiatry Res, 2008; 162(3): 221-29
30. Gelernter J, Kranzler H, Cubells JF: Serotonin transporter protein (SLC6A4) allele and haplotype frequencies and linkage disequilibria in African- and European-American and Japanese populations and in alcohol-dependent subjects. Hum Genet, 1997; 101(2): 243-46

31. Hranilovic D, Stefulj J, Schwab S et al: Serotonin transporter promoter and intron 2 polymorphisms: Relationship between allelic variants and gene expression. Biol Psychiatry, 2004; 55(11): 1090-94

32. Safarinejad MR: Analysis of association between the 5-HTTLPR and STin2 polymorphisms in the serotonin-transporter gene and clinical response to a selective serotonin reuptake inhibitor (sertraline) in patients with premature ejaculation. BJU Int, 2009; 105(1): 73-78

\section{4}

Indexed in: [Current Contents/Clinical Medicine] [SCI Expanded] [ISI Alerting System] [ISI Journals Master List] [Index Medicus/MEDLINE] [EMBASE/Excerpta Medica] [Chemical Abstracts/CAS] [Index Copernicus] 